Powell, J. F. \& Hunter, J. R. (1955). J. gen. Microbiol. 13, 54-58,

\title{
The Sporulation of Bacillus sphaericus stimulated by As- sociation with other Bacteria: an Effect of Carbon Dioxide
}

\author{
BY JOAN F. POWELL AND J. R. HUNTER \\ Microbiological Research Department (Ministry of Supply), Porton, Wiltshire
}

SUMMARY : Sporulation of Bacillus sphaericus, NCTC 7582, in a complex medium was strongly stimulated by growth in mixed culture with a sporing strain of $B$. cereus and with sporogenous and asporogenous strains of B. subtilis, NCTC 85. There was a similar, but less pronounced, effect with a variety of Gram-positive and Gramnegative organisms. The degree of sporulation of $B$. sphaericus in these mixed cultures depended on $(a)$ an external stimulus from the medium and $(b)$ the previous cultural history of the $B$. sphaericus inoculum upon which depended its ability to respond to the external stimulus. Sporulation of $B$. sphaericus in pure culture was strongly stimulated by bicarbonate and ketoglutarate, suggesting that increased carbon dioxide production was the stimulating factor in mixed cultures.

The stimulatory effect of one organism upon the growth of another has been observed in bacteria and in fungi (e.g. Grassberger, 1897; Bacon, Burrows \& Yates, 1951; Hawker, 1947). In fungi there are examples of stimulation of both growth and sporulation in mixed cultures (Asthana \& Hawker, 1936; Hawker, 1939). This report describes a similar phenomenon in the genus Bacillus and suggests a mechanism for the effect.

\section{ORGANISMS AND ME'THODS}

A culture of Bacillus sphaericus, NCTC 7582, grown for $24 \mathrm{hr}$. at $37^{\circ}$ on casein hydrolysate yeast extract (CCY) agar (Gladstone \& Fildes, 1940) was suspended in $50 \mathrm{ml}$. glucose serum broth (Fry \& Greaves, 1951) and freeze-dried in $5 \mathrm{ml}$. batches. Starting with one of these freeze-dried batches, a series of sporulation tests was made, during which time the organism was maintained by subculturing every $48 \mathrm{hr}$. on CCY agar, and on potato-extract agar (Robinow, 1951) enriched with 1/10 vol. of CCY medium (Pot. CCY).

The strongly sporing strain of Bacillus cereus isolated from air and the sporogenous and asporogenous strains of Bacillus subtilis, NCTC 85, were maintained on CCY agar. The other organisms used were subcultured at least twice in Pot. CCY medium before the mixed culture tests.

For the sporulation tests, which were set up in duplicate, $10 \mathrm{ml}$. batches of liquid Pot. CCY medium in $50 \mathrm{ml}$. conical flasks were inoculated with $0.5 \mathrm{ml}$. of a just visibly turbid suspension of organisms and shaken at $37^{\circ}$ for periods up to $36 \mathrm{hr}$.

\section{RESULTS}

There was rapid growth and remarkably vigorous sporulation of Bacillus cereus and $\boldsymbol{B}$. subtilis in the test medium, which was selected for this reason. The first signs of sporulation appeared at $14 \mathrm{hr}$., and at $17 \mathrm{hr}$. almost every 
cell contained a well-developed spore. B. sphaericus taken from the first CCY agar subcultures showed approximately 1-5\% sporulation after $36 \mathrm{hr}$. At $18 \mathrm{hr} . \mathbf{2 0 - 3 0 \%}$ of the cells appeared to have reached a half-way stage of sporulation, but disintegrated before the spore had properly developed. After about twenty subcultures on CCY agar, although growth in the test medium was not diminished, the sporing ability of the organism became almost negligible, until finally no sign of sporulation could be detected. During this time the effect of inoculating test flasks with both $B$. cereus and $B$. sphaericus was also studied. The first $B$. sphaericus subcultures, with some tendency to sporulate when grown alone, showed almost complete sporulation after $18 \mathrm{hr}$. growth with $B$. cereus (Pl. 1, figs. 1, 2). Later subcultures, which showed no sign of sporulation when grown alone, were stimulated to produce pre-spores, i.e. refractile non-staining areas in the presence of $B$.cereus, and then appeared to disintegrate. After further subcultures on CCY agar, B. sphaericus lost its ability to respond to the $B$. cereus stimulus.

When an original freeze-dried stock culture of Bacillus sphaericus was maintained by subculture on Pot. CCY agar, there was a marked increase of sporing ability in pure culture. Similarly, cultures which had become asporogenous after repeated subculture on CCY agar, sometimes regained their ability to sporulate after approximately twenty subcultures on Pot. CCY agar. Thus, of four such asporogenous cultures, two regained their original sporing ability completely. The other two remained asporogenous but produced cells containing large granules staining black by the Albert (1921) method and purplish pink with methylene blue and toluidine blue. Some of the granules appeared to be free. Examined in wet preparation, the granules were less refractile than developing spores from which they could readily be distinguished. The phosphorus : nitrogen ratio in washed cells from a 'granular' culture was $\mathbf{0 \cdot 3 7}$ compared with $\mathbf{0 . 2 6}$ in a culture not containing granules. The granules therefore probably contained volutin, i.e. polymetaphosphate (Wiame, 1947).

Sporogenous cultures of Bacillus sphaericus grown for $16 \mathrm{hr}$. in Pot. CCY medium were centrifuged and the cells resuspended in the medium from 9 and $14 \mathrm{hr}$. cultures of $B$. cereus. After $5 \mathrm{hr}$. shaking there was only poor sporulation, but large purple-pink granules appeared in most cells ( $\mathrm{Pl}$. 1, figs. 4, 5). The appearance of these resuspended cultures was similar to that of the asporogenous granular cultures just described (Pl. 1, fig. 3). After $24 \mathrm{hr}$. shaking, the resuspended culture consisted almost entirely of non-sporulating cells free from large granules. Similar results were obtained with $10 \mathrm{hr}$. cultures of $B$. sphaericus.

A slight stimulation of Bacillus sphaericus sporulation was observed when the organism was grown in a cellophan tube immersed in a shaken growing culture of $B$. cereus, but this result was not always repeatable.

The effect of growing Bacillus sphaericus in mixed culture with other organisms was then studied. Both the sporogenous and asporogenous strains of $B$. subtilis stimulated rapid and almost complete sporulation of the feebly sporing $B$. sphaericus, and increased the 'granulation' of the asporogenous strain. Staphylococcus aureus (Oxford strain), Corynebacterium xerosis 
NCTC 7904, and laboratory strains of Chromobacterium prodigiosum (Serratia marcescens) and a Leuconostoc species had a similar but less pronounced effect. Escherichia coli, NCTC 1100, and a laboratory strain of Pseudomonas aeruginosa (pyocyanea) grew well in mixed culture with Bacillus sphaericus but had no apparent effect on its sporulation.

Bacillus sphaericus cells resuspended in culture fluid from a stimulating organism showed very poor sporulation (see above). It appeared therefore that the stimulus in mixed culture was produced during associated growth of the stimulating organism, and was probably due to some non-specific effect such as (i) a more rapid exhaustion of nutrients in mixed culture, or (ii) a reduction of dissolved oxygen or an increase of carbon dioxide concentration in the medium to some critical level. The effect of adding $0.04 \mathrm{M}$-sodium bicarbonate to the medium as a means of increasing carbon dioxide concentration was next tested. Control flasks were adjusted to the same $\mathrm{pH}$ as those to which bicarbonate was added, i.e. $\mathrm{pH} 8 \cdot 2$. At $18 \mathrm{hr}$. there was very poor sporulation in the controls, but almost complete sporulation in the presence of bicarbonate (Pl. 1, figs. 6, 7). Final $\mathrm{pH}$ values were $9 \cdot 0$ and $\mathbf{9 \cdot 2}$ respectively. There was equally strong stimulation of sporulation in the presence of $0.04 \mathrm{M}-$ ketoglutarate ( $\mathrm{Pl}$. 1, figs. 8,9 ) with initial and final $\mathrm{pH}$ values of $7 \cdot 6$ and $8 \cdot 7$ both in the controls and ketoglutarate media. Although the other possibilities mentioned above were not explored, it seemed highly probable that stimulation of $\boldsymbol{B}$. sphaericus sporulation in mixed culture was due to increased carbon dioxide concentration in the medium.

\section{DISCUSSION}

Under the conditions described it appeared that the degree of sporulation of Bacillus sphaericus depended on (a) a stimulus from the medium which could be intensified by growth in mixed culture with a variety of bacteria, and (b) an intracellular factor which controlled the ability of the cell to respond to the outside stimulus. Although a high $\mathrm{CO}_{2}$ concentration in the medium may not have been of prime importance for the initiation of sporulation, its presence appeared to be essential in order to make the process rapid and complete. This may hold for sporing organisms in general, since it has been repeatedly observed that rapid and complete sporulation occurs after a period of vigorous growth, i.e. high $\mathrm{CO}_{2}$ production. It is specially interesting in this connexion that Cantino (1952) showed that bicarbonate stimulated the production of thick-walled resistant sporangia in the mould Blastocladiella. The function of $\mathrm{CO}_{2}$ as a sporulation stimulant in the genus Bacillus may be connected with its possible stimulatory effect on dipicolinic acid synthesis (Powell, 1953). It seems likely, especially since conversion of lysine to pipecolic acid has been demonstrated (Rothstein \& Miller, 1953; Lowy, 1953) that dipicolinic acid is derived from $\alpha \epsilon$-diaminopimelic acid by deamination followed by ring closure and dehydrogenation. It is possible that $\mathrm{CO}_{2}$, by inhibiting the decarboxylation of $\alpha \epsilon$-diaminopimelic acid (an effect already observed by Hoare \& Work, 1954, personal communication), might allow the 
deamination reaction and subsequent build-up of dipicolinic acid to proceed more rapidly.

In this investigation we obtained an asporogenous culture of Bacillus sphaericus by repeated subculture of the organism on a relatively rich medium (CCY). The sporulating power of this culture was in some cases restored by repeated transfer to a less nutritious medium (Pot. CCY). The sensitivity, i.e. the degree of response of a vegetative cell of $B$. sphaericus to the external stimulus, may depend on its ability to divert one or more metabolic pathways in 'abnormal' directions, e.g. for the synthesis of dipicolinic acid, and it is possible that this ability might be enhanced or lowered by adaptive processes on different media, or by variation (Brunstetter \& Magoon, 1932; Schmidt, 1950). We found that there was often an increased production of volutin by the asporogenous strain of $B$. sphaericus under conditions which stimulated sporulation of the sporogenous strain. This was not due to the development of acid conditions in the culture (cf. Duguid, Smith \& Wilkinson, 1954). It may represent an incomplete response to the external stimulus, i.e. a derangement of metabolism in cells whose metabolic path was blocked as a result of conditions in the medium and could not be diverted in the direction of sporulation. There was also volutin production in sporogenous cells, especially after resuspension in culture medium from a stimulating organism. This may again represent an incomplete response in cells which were capable of sporulation but were receiving an insufficiently sustained stimulus from the medium to drive the sporulation process to completion.

We wish to thank Mrs W. Fryer for technical assistance and Mr R. E. Strange for nitrogen and phosphorus analyses. Acknowledgement is made to the Chief Scientist, Ministry of Supply, for permission to publish this paper.

\section{REFERENCES}

Albert, H. (1921). Modification of stain for diphtheria bacilli. J. Amer. med. Ass. 76, 240.

Asthana, R. P. \& Hawker, L. E. (1936). The influence of certain fungi on the sporulation of Melanospora destruens Shear and of some other ascomycetes. Ann. Bot., Lond. 50, 325.

Bacon, G. A., Burrows, T. W. \& Yates, M. (1951). The effects of biochemical mutation on the virulence of Bacterium typhosum: the loss of virulence of certain mutants. Brit. J. exp. Path. 32, 85.

Brunstetter, B. C. \& Magoon, C. A. (1932). Studies on bacteria spores. III. A contribution to the physiology of spore production in Bacillus mycoides. J. Bact. 24, 85.

Cantino, E. C. (1952). The biochemical nature of morphogenic patterns in Blastocladiella. Amer. Nat. 86, 399.

Duguid, J. P., Smith, I. W. \& Wilkinson, J. F. (1954). Volutin production in Bacterium aerogenes due to development of an acid reaction. J. Path. Bact. 67, 289.

Fry, R. M. \& Greaves, R. I. N. (1951). The survival of bacteria during and after drying. J. Hyg., Camb. 49, 220.

Gladstone, G. P. \& Fildes, P. (1940). A simple culture medium for general use without meat extract or peptone. Brit. J. exp. Path. 21, 161. 
Grassberger, R. (1897). Beiträge zur Bakteriologie der Influenza. Z. Hyg. Infekt $K r .25,453$.

HAwkER, L. E. (1939). The nature of the accessory growth factors influencing growth and fruiting of Melanospora destruens Shear and of some other fungi. Ann. Bot., Lond., N.S. 3, 657.

Hawker, L. E. (1947). Further experiments on growth and fruiting of Melanospora destruens Shear in the presence of various carbohydrates with special reference to the effects of glucose and sucrose. Ann. Bot., Lond. N.S. 11, 245.

Lowy, P. (1953). The conversion of lysine to pipecolic acid by Phaseolus vulgaris. Arch. Biochem. Biophys. 47, 228.

Powell, J. F. (1953). Isolation of dipicolinic acid (pyridine 2:6 dicarboxylic acid from spores of Bacillus megatherium. Biochem. J. 54, 210.

Robinow, C. F. (1951). Observations on the structure of Bacillus spores. J. gen. Microbiol. 5, 439.

Rothstein, M. \& Miller, L. L. (1953). The conversion of L-lysine-6-C ${ }^{14}$ to pipecolic acid in the rat. J. Amer, chem. Soc. 75, 4371.

Schmidt, C. F. (1950). Spore formation by thermophilic flat sour organisms. I. The effect of nutrient concentration and the presence of salts. J. Bact. 60, 205.

Wiame, J. M. (1947). The metachromic reaction of hexametaphosphate. J. Amer. chem. Soc. 69, 3146.

\section{EXPLANATION OF PLATE}

All films heat-fixed and stained with methylene blue. Magnification $\times 1500$.

Fig. $1.18 \mathrm{hr}$. sporogenous $B$. sphaericus in pure culture.

Fig. 2. $18 \mathrm{hr}$. sporogenous $B$. sphaericus in mixed culture with $B$. cereus.

Fig. 3. $18 \mathrm{hr}$. asporogenous $B$. sphaericus subcultured repeatedly on Pot. CCY agar, showing granule production in test medium at $\mathrm{pH} 8 \cdot 1$.

Fig. 4. 21 hr. sporogenous B. sphaericus.

Fig. 5. $16 \mathrm{hr}$. sporogenous $B$. sphaericus resuspended for $5 \mathrm{hr}$. in $B$. cereus medium.

Fig. 6. $18 \mathrm{hr}$. sporogenous $B$. sphaericus at $\mathbf{p H ~ 9 . 0 .}$

Fig. 7. $18 \mathrm{hr}$. sporogenous $B$. sphaericus sporulating with $0.04 \mathrm{M}$-bicarbonate at $\mathrm{pH} 9 \cdot 2$.

Fig. 8. $18 \mathrm{hr}$. sporogenous $B$. sphaericus at $\mathrm{pH} \mathrm{8.7.}$

Fig. 9. $18 \mathrm{hr}$. sporogenous $B$. sphaericus sporulating with $0.04 \mathrm{M}-\mathrm{ket}$-glutarate at $\mathrm{pH} 8.7$. 
Journal of General Microbiology, Vol. 13, No. 1
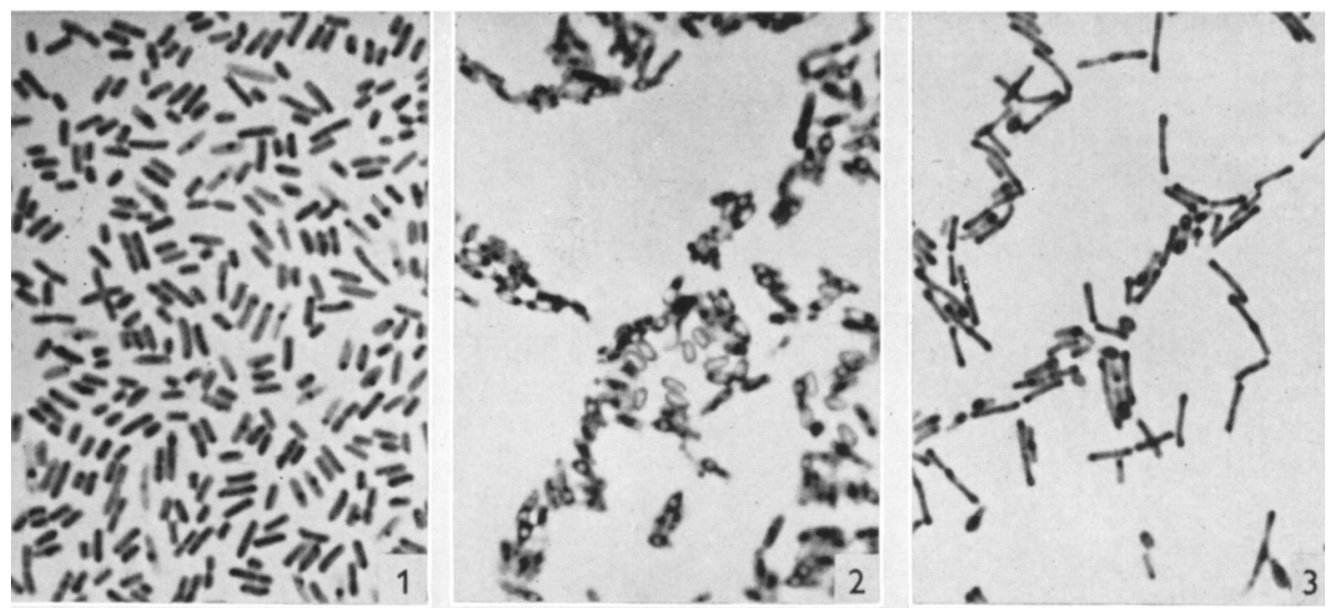

(1)
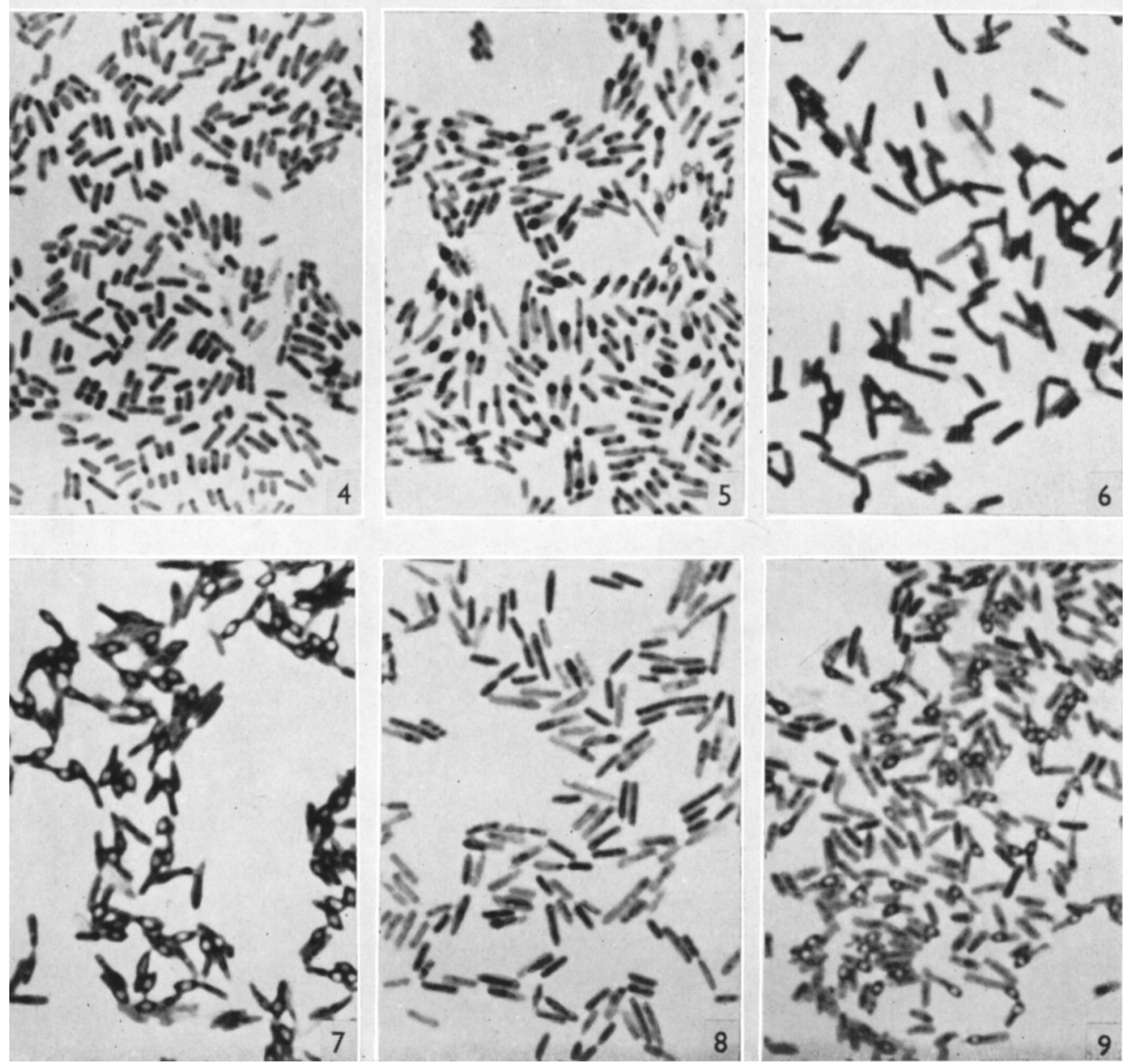

J. F. Powell and J. R. Hunter-Sporvlation of b. sphakrieus. Plate 1. 